\title{
PROTOTIPE SISTEM KEAMANAN RUANGAN MENGGUNAKAN FINGER PRINT DAN KEYPAD MATRIX DENGAN ONE TIME PAD
}

\author{
Rahmita Pasmah ${ }^{1}$, Abdul Jabbar Lubis ${ }^{2}$, Ari Usman ${ }^{3}$ \\ $1,2,3$ * Universitas Harapan Medan, Medan, Indonesia \\ Email:29rahmita.pasmah@gmail.com
}

\begin{abstract}
Abstrak-Perancangan sistem keamanan ruangan menggunakan finger print dan keypad matriks dengan One Time Pad (OTP) pada ruang Dekan Fakultas Teknik dan Komputer di Universitas Harapan Medan dikarenakan masih menggunakan keamanan konvensional. Dengan keamanan yang tidak selalu dijaga terutama diluar jam kerja, maka penulis menbuat perancangan sistem keamanan ruangan untuk membuka ruangan hanya dengan sidik jari yang telah didaftarkan dan nomor telepon aktif yang sudah terprogram, sehingga tidak dapat di akses oleh orang lain. Perancangan ini dibuat dengan beberapa komponen yaitu arduino sebagai pengolah data sistem kerja seluruh rangkaian, pembaca sidik jari berfungsi untuk mengenali sidik jari yang akan didaftarkan, untuk memasukan kode OTP menggunakan keypad matrix, Liquid Crystal Display (LCD) untuk menampilkan data yang diberikan arduino melalui program yang telah dibuat, relay untuk mengaktifkan solenoid, solenoid berfungsi untuk membuka atau mengunci pintu, buzzer akan berbunyi ketika sidik jari dan password tidak terbaca, modul GSM SIM900A berfungsi untuk mengirim kode OTP dengan menggunakan nomor telepon seluler yang aktif, dan sensor magnet MC-38 untuk mengetahui pintu telah terbuka atau masih tertutup. Dari pengujian ini dapat disimpulkan bahwa hanya sidik jari orang yang sudah didaftarkan dan nomor telepon yang sudah di program untuk dapat membuka pintu ruangan. Jika pola sidik jari tidak terdaftar makan alarm akan berbunyi.
\end{abstract}

Kata Kunci: Finger Print, One Time Pad, GSM SIM900, Keypad Matrix

\begin{abstract}
Abstact-The room security system design uses finger print and a matrix keypad with One Time Pad (OTP) in the Dean's room, Faculty of Engineering and Computers at Universitas Harapan Medan because it still uses conventional security. With security that is not always maintained, especially outside working hours, the authors make a room security system design to open the room only with registered fingerprints and programmed active telephone numbers, so that it cannot be accessed by others. This design is made with several components, namely Arduino as a data processor for the entire work system, the fingerprint reader functions to recognize the fingerprints to be registered, to enter the OTP code using the matrix keypad, Liquid Crystal Display (LCD) to display the data provided by Arduino through the program. that has been made, the relay is used to activate the solenoid, the solenoid functions to open or lock the door, the buzzer will sound when the fingerprint and password are not read, the GSM SIM900A module functions to send an OTP code using an active cell phone number, and the MC-38 magnetic sensor to know if the door is open or still closed. From this test it can be concluded that only the fingerprints of people who have been registered and the telephone numbers that have been programmed to be able to open the door of the room. If the fingerprint pattern is not registered then an alarm will sound.
\end{abstract}

Keywords: Finger Print, One Time Pad, GSM SIM900, Keypad Matrix

\section{PENDAHULUAN}

Pada era globalisasi seperti saat ini perkembangan ilmu pengetahuan khususnya dalam penerapan teknologi dan informasi, baik itu elektronika maupun robotika dengan persaingan menciptakan berbagai teknologi yang lebih handal dalam membantu dan meringankan beban kerja manusia. Hal ini dapat dilihat dari semakin banyaknya peralatan elektronik dalam kehidupan sehari-hari yang serba otomatis, dari penggunaan teknologi yang sederhana hingga teknologi yang canggih.

Banyak peneliti yang membuat sebuah sistem keamanan ruangan yang telah berkembang luas seperti aplikasi dalam mengontrol sistem keamanan pintu geser dengan menggunakan password yang dikontrol menggunakan mikrokontroller. Banyak sistem keamanan yang makin canggih seperti penggunaan sensor sidik jari yang sudah banyak digunakan sebagai presensi. Pola sidik jari untuk sistem keamanan sangat tinggi dan telah banyak digunakan diperkantoran, perusahaan, sekolah, pemerintah dan lain-lain karena biometri dari sidik jari tidak mudah dipalsukan [1], [2], [3].

Algoritma OTP (One Time Pad) kuat dan aman apabila memenuhi kriteria pengoperasian dalam mengecek kunci secara random dan tidak menggunakan kunci untuk operasi lain. OTP melakukan proses dengan enkripsi dan dekripsi yang menjadi kelebihannya dalam menyamarkan pesan yang termuat pada media tertentu. Dalam sistem keamanan rumah, sidik jari digunakan oleh penghuni rumah untuk akses membuka atau menutup pintu masuk utamanaya. Kerena sidik jari unik sehingga tidak mudah bagi pihak lain untuk masuk ke rumah. Sistem ini dapat melindungi warga dan rumah sehingga tidak mudah diakses oleh orang yang tidak dikenal [4], [5]. 
OTP adalah salah satu metode enkripsi yang cukup handal dengan menggunakan hashing pada enkripsi dan kompresinya dengan membantu pengamanan melalui SMS (Short Messsage Service). Perancangan ini juga menggunakan SIM 900A dan mengirim kode OTP melalui SMS. Di Indonesia SMS banyak digunakan dalam berkomunikasi serta mengirim informasi pada penggunanya. SMS dapat digunakan sebagai akses pengendali jarak jauh yang dikendalikan oleh komponen elektronik tanpa ada salah pengiriman informasi pada perangkat tersebut kapanpun dan dimanapun. Metode pengiriman SMS melalui aplikasi android dalam sistem membuka kunci otomatis dengan pengiriman SMS melalui aplikasi android dan tidak membutuhkan kontrol akses berupa alat fisik [6], [7], [8].

Dalam perancangan penulis menggunakan arduino uno atau sebuah board yang berbasis mikrokontroler ATmega328. Arduino didukung dengan bahasa pemprograman yang dikenal dengan arduino IDE dalam melakukan pengiriman intruksi ke mikrokontroler. Penelitian yang menerapkan metode pencurian yang ada pada smartphone agar dapat digunakan juga oleh perangkat lain seperti pintu sebuah ruangan yang keamanannya berbasis mikrokontroler Atmega 328 dan Pattern Unclock Smartophone Android [9], [10].

Tujuan penelitian ini menghasilkan sistem pengamanan ruangan yang memanfaatkan pola sidik jari yang didaftarkan dan password OTP yang dikirim ke nomor telepon pemilik ruangan sebagai pengamanan yang efektif sehingga tidak dapat diakses oleh orang lain.

\section{METODE PERANCANGAN}

Perancangan sistem keamanan ruangan yang dikembangkan dalam penelitian ini menggunakan dua tahapan yaitu perancangan sistem menggunakan finger print dan one time pad. Perancangan sistem keamanan ini digunakan untuk mengamankan seluruh yang ada diruangan untuk menghindari aksi kejahatan maupun pencurian. Sistem ini juga dilengkapi dengan alarm ketika sidik jari yang diinput tidak terdaftar pada sistem.

Perancangan sistem keamanan yang dikembangkan terdiri dari tiga blok sistem yaitu input, proses, dan output[11]. Input sistem terdiri dari finger print dan keypad matrix. Sistem pemprosesan data dikendalikan oleh arduino uno. Output sistem terdiri dari LCD, sensor MC-38, relay, solenoid, buzzer dan modul GSM SIM 900. Berikut adalah blok diagram sistem keamanan ruangan yang ditunjukkan pada Gambar 1.

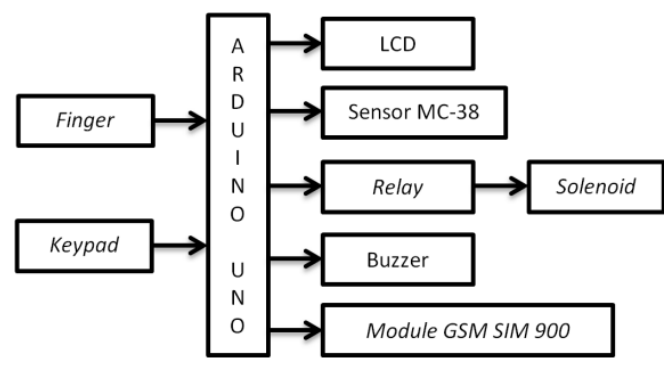

Gambar 1. Blok Diagram Sistem

\section{HASIL DAN PEMBAHASAN}

\subsection{Flowchart Sistem Keamanan Ruangan}

Diagram alir sistem adalah gambaran yang memperlihatkan aliran data dari sumber dalam objek kemudian melewati satu proses yang mentransformasikan ketujuan yang lain. 


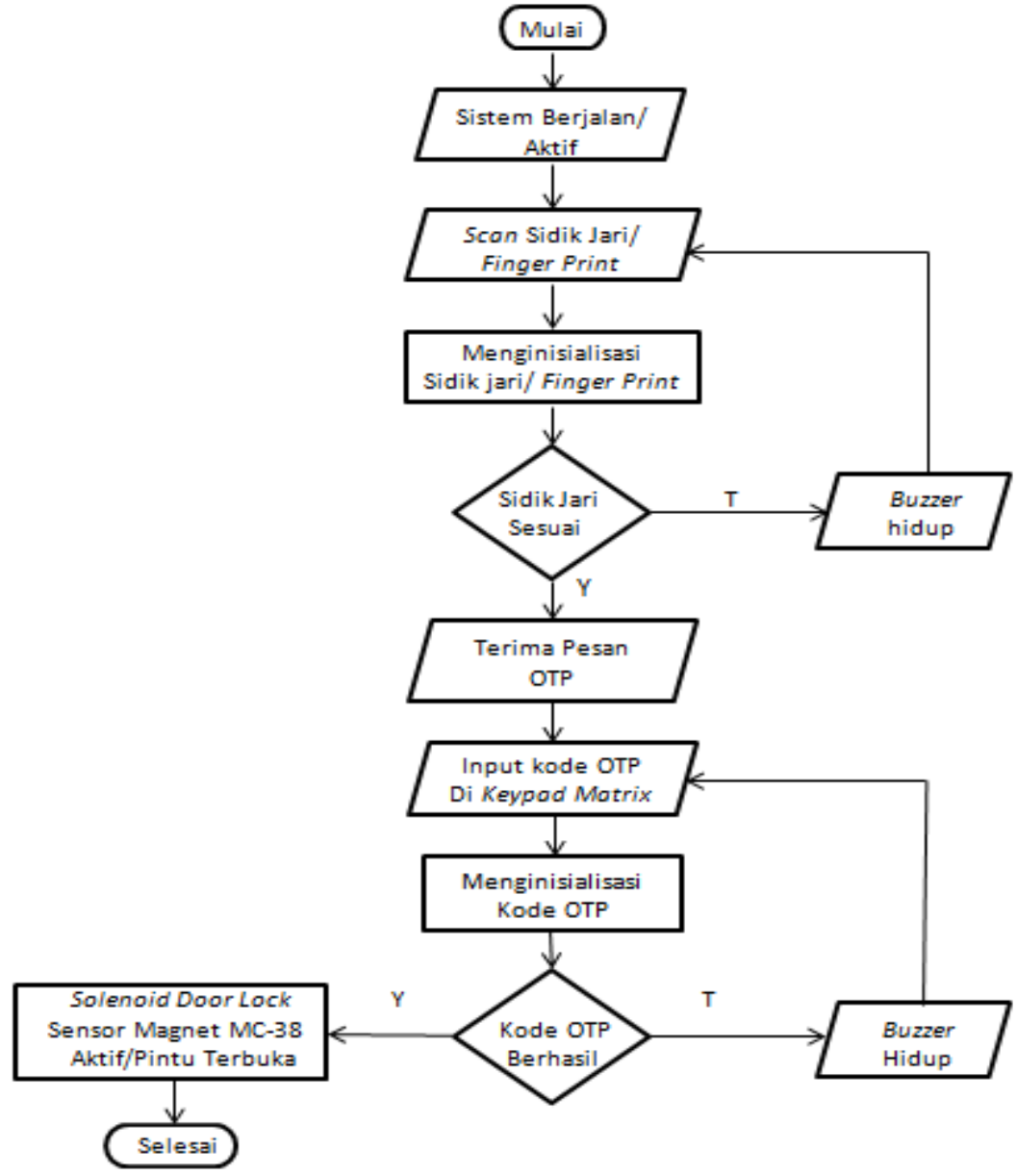

Gambar 2. Flowchart Sistem Keamanan Ruangan

\subsection{Implementasi}

Pengujian dilakukan untuk mengetahui kerja sistem pada masing-masing rangkaian yang dibuat yaitu pengujian penginputan finger print dan kode acak dengan one time pad. Berikut ini adalah beberapa hasil pengujian yang telah dilakukan yaitu:

a. Pengujian pertama yaitu apakah penginputan sidik jari/finger print yang sudah didaftarkan dapat terinisialisai oleh sensor finger print.

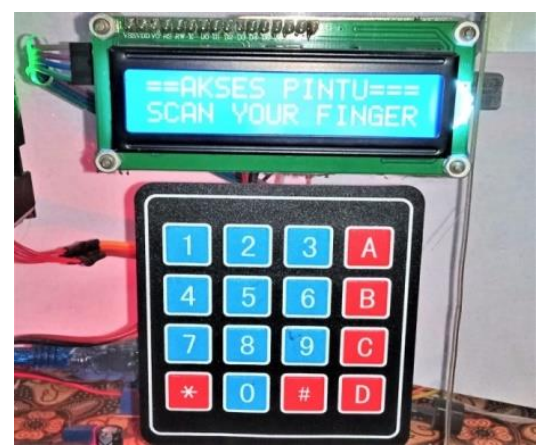

Gambar 3. LCD Menunjukan Scan Your Finger

Gambar 3 merupakan tampilan awal dan akses utama membuka pintu pada rangkaian sistem keamanan ruangan. Untuk membuka pintu raungan, terlebih dahulu pengguna mendaftarkan sidik jarinya. 


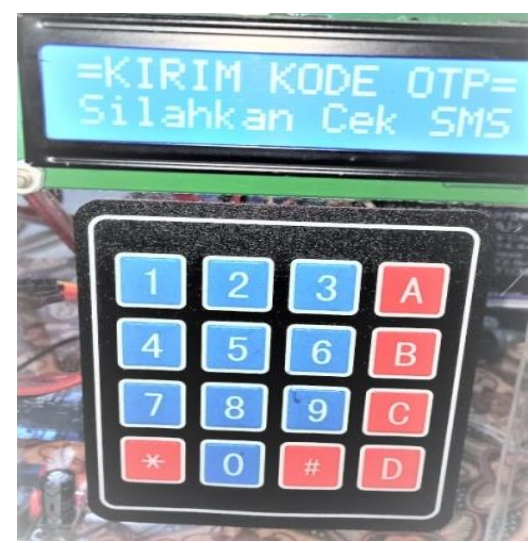

Gambar 4. Scan Sidik Jari Pada Ruangan Berhasil

Gambar 4 adalah tampilan ketika scan sidik jari/finger print yang berhasil di input. Pada tahap ini, Arduino mengirimkan kode OTP melalui SMS pada nomor tujuan yang telah didaftarkan. Selanjutnya sistem akan menampilkan "Input OTP dr SMS" yang tertera di layar LCD. Gambar 5 merupakan tampilan untuk menginputkan kode OTP yang dikirim melalui SMS pada nomor tujuan. Kode OTP yang dikirimkan hanya 6 digit dan berupa Angka seperti yang ditunjukan gambar 5 .

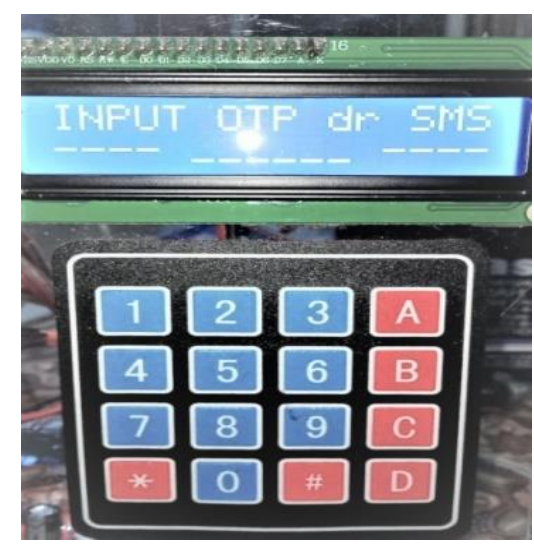

Gambar 5. Tampilan meminta menginput kode OTP dari SMS.

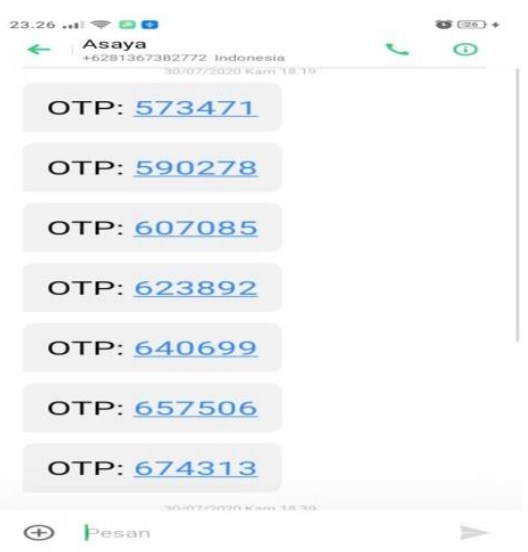

Gambar 6. Pesan kode OTP. 


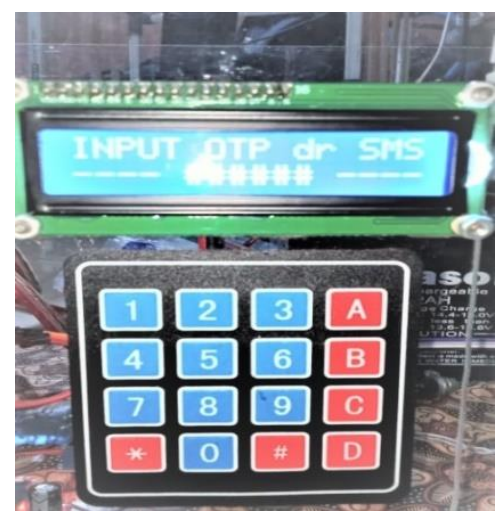

Gambar 7. Tampilan Penginputan Kode OTP dari SMS.

Langkah terakhir untuk membuka pintu ruangan setelah penginputan sidik jari/finger print yaitu menginputkan kode OTP ke keypad matrix seperti yang ditunjukan gambar 7. Jika penginputan sidik jari/finger print berhasil, sistem akan mengarahkan pada pengiriman kode OTP melalui SMS ke nomor tujuan yang telah didaftarkan. Selanjutnya kode OTP di input dengan keypad matrix sebagai langkah akhir membuka pintu ruangan. Kemudian LCD akan menampilan "Silakan Buka Kunci Terbuka” seperti yang ditunjukan gambar 8.

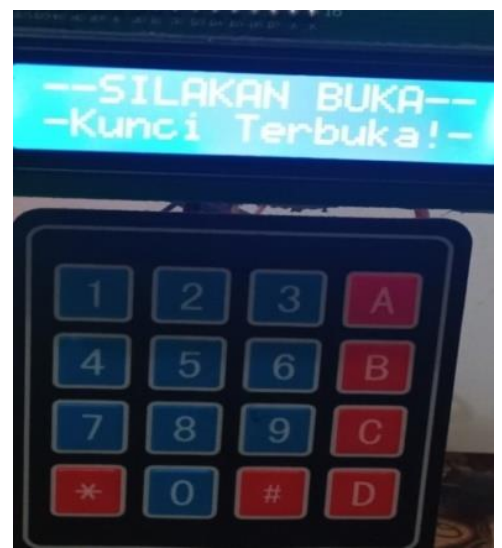

Gambar 8. Buka Pintu Berhasil..

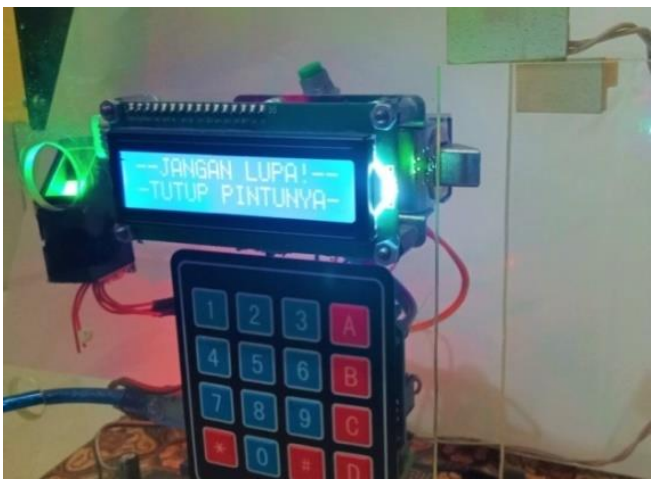

Gambar 9. Tampilan Ketika Pintu Telah Terbuka dan Mengingatkan Untuk Menutup Pintu.

Pada pengujian pertama yang telah diuji coba diperoleh bahwa pola sidik jari berhasil diinisialisasi dengan baik, karena jika pola sidik jari sesuai maka pintu ruangan mengarahkan pada kode acak. Kode acak dan penginputan kode OTP melalui SMS ke nomor tujuan pada pengujian ini juga berhasil dan pintu terbuka. 
b. Pengujian kedua yaitu apa yang terjadi ketika sidik jari/finger print tidak sesuai.

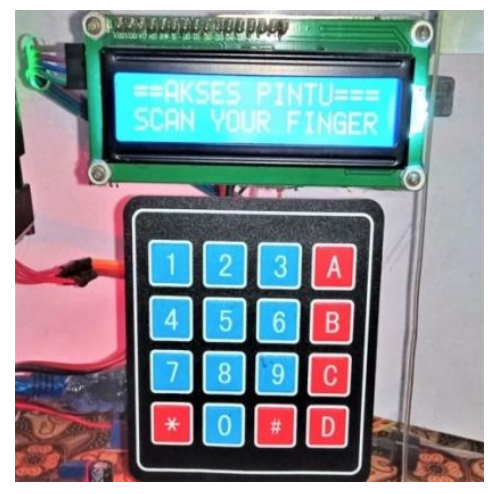

Gambar 10. LCD Menunjukan Scan Your Finger.

Gambar 10 merupakan tempilan awal dan akses utama membuka pintu pada rangkaian sistem keamanan ruangan. Untuk mengetahui sidik jari yang tidak sesuai maka penulis menggunakan salah satu jari yang belum didaftarkan. Jika sidik jari tidak terdaftar atau error maka sistem menginisialisasi dan memproses yang kemudian menampilkan output "Sidik Jari Tidak Sesuai” yang ditunjukan pada gambar 11.

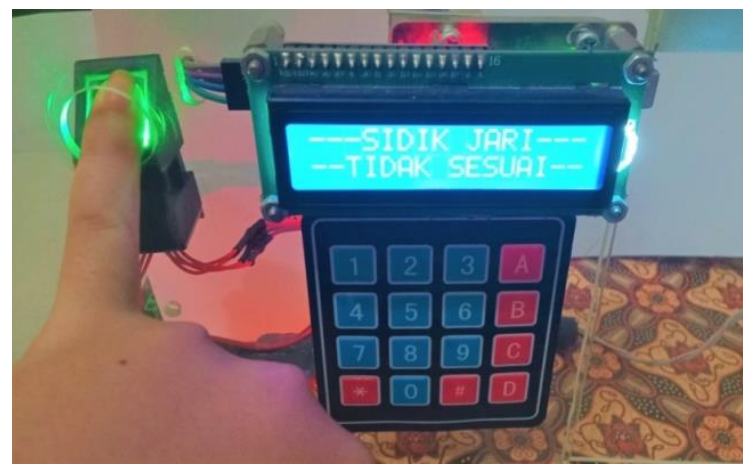

Gambar 11. Inisisalisasi Sidik Jari Tidak Sesuai.

Pada pengujian kedua yang telah diuji coba diperoleh bahwa ketika penginisialisasi sidik jari tidak cocok maka buzzer akan berbunyi dan LCD menampilkan pesan "sidik jari tidak sesuai". Setelah penginisialisasian LCD akan kembali ke tampilan awal serta solenoid door lock dan sensor magnet MC-38 tetap terkunci. Pengamanan dengan finger print ini dapat dikatakan aman karena hanya dapat dibuka pada pola sidik jari yang telah didaftarkan.

c. Pengujian ketiga yaitu apa yang terjadi ketika penginputan kode OTP tidak sesuai.

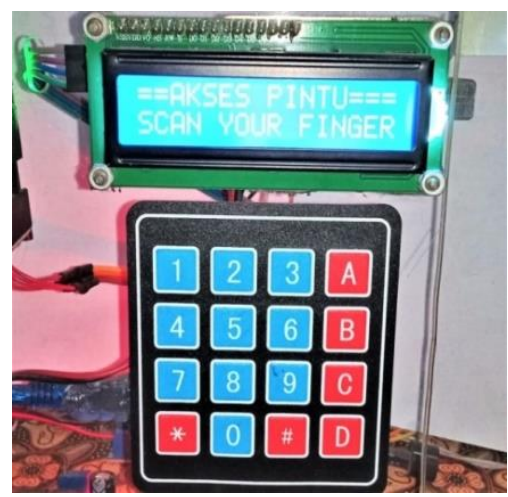

Gambar 12. LCD Menunjukan Scan Your Finger

Gambar 12 merupakan tempilan awal dan akses utama membuka pintu pada rangkaian sistem keamanan ruangan, sama seperti pada langkah sebelumnya Untuk mendapatkan kode OTP, pengguna diharuskan untuk scan sidik jari/finger print. Gambar 13 merupakan tampilan ketika sidik jari terdeteksi. 


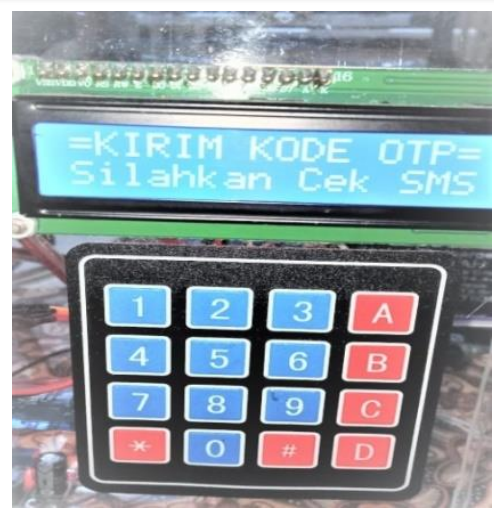

Gambar 13. Scan Sidik Jari Pada Ruangan Berhasil

Ketika penginputan sidik jari berhasil sistem langsung menampilkan "Input OTP dr SMS" di layar LCD seperti gambar 1. Gambar 14 merupakan tampilan untuk menginputkan kode OTP yang dikirim melalui SMS pada nomor tujuan. Kode OTP yang dikirimkan hanya 6 digit dan berupa angka.

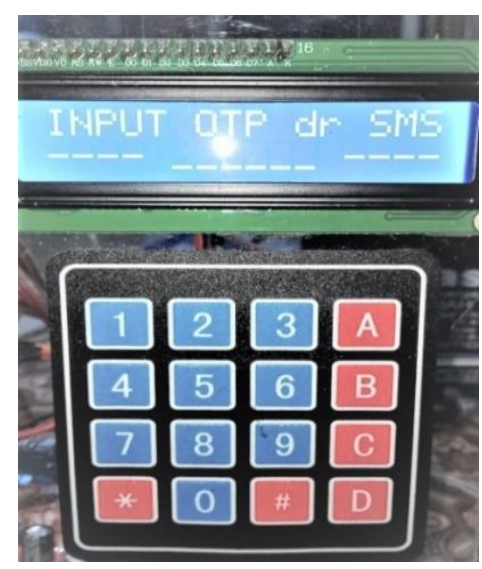

Gambar 14. Tampilan meminta menginput kode OTP dari SMS.

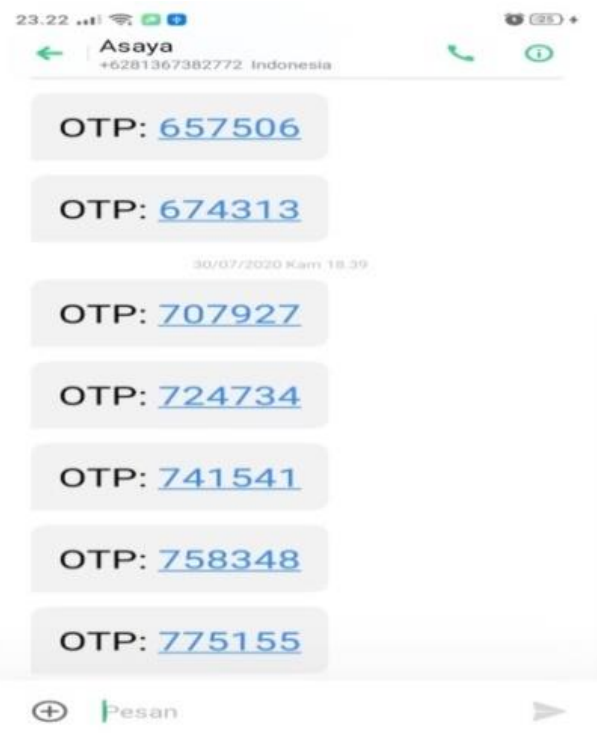

Gambar 15. Pesan kode OTP. 


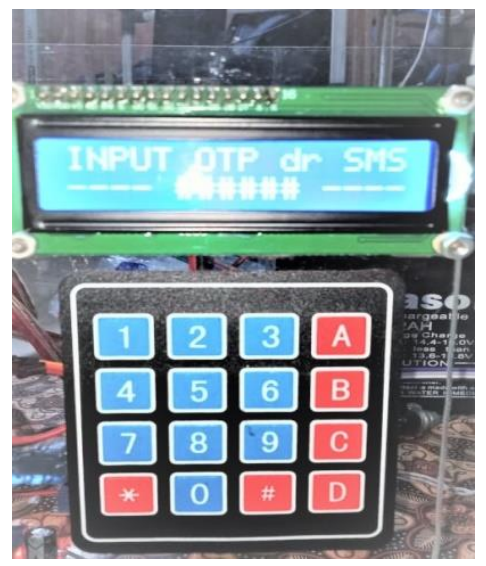

Gambar 16. LCD Menginputkan Angka dari Kode OTP untuk Membuka Pintu.

Gambar 16 adalah tampilan hasil input kode OTP yang diterima dari pesan SMS yang telah dikirimkan.

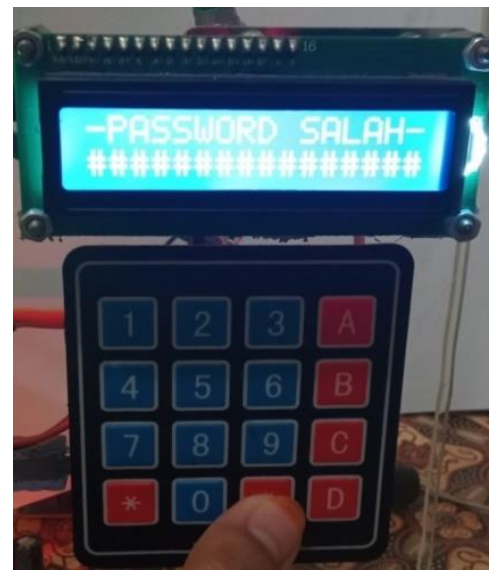

Gambar 17. Penginputan Kode OTP Pada Ruangan Salah.

Gambar 17 merupakan hasil proses ketika kode OTP salah di input. Jika kode OTP di input tidak sesuai, maka sistem akan kembali pada perintah isi kode OTP kembali yang ditunjukan gambar 16.

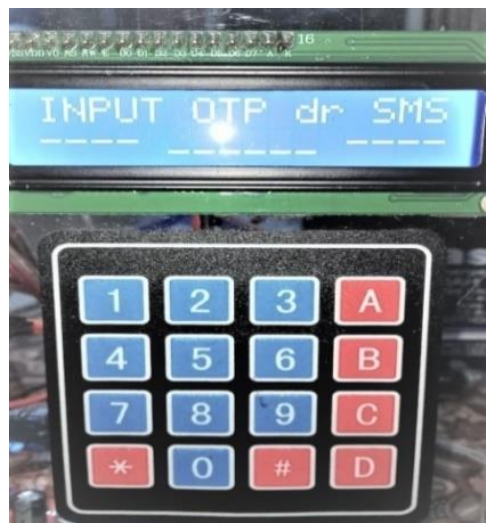

Gambar 18. LCD Menginputkan Angka Kode OTP kembali.

Pada pengujian ketiga yang telah diuji coba diperoleh bahwa, ketika penginputan kode acak salah maka akan muncul pesan "Password Salah" dan proses akan kembali pada tampilan "Tekan Password". Pada tahap 
penginputan pada keypad matrix jika password salah maka buzzer akan berbunyi dan solenoid door lock dan sensor magnet MC-38 akan kembali terkunci. Pengamanan ini dapat dikatakan aman karena kode acak yang dikirim hanya satu kali proses dan kode OTP yang diproses hanya untuk satu kali digunakan.

Tabel 1. Hasil Pengujian Sistem

\begin{tabular}{|c|c|c|}
\hline No. & Sistem Pengujian & Keterangan Hasil \\
\hline 1. & $\begin{array}{l}\text { Bagaimana sistem pengujian Sidik jari/finger } \\
\text { print dan kode OTP yang berhasil? }\end{array}$ & $\begin{array}{l}\text { Sebelum penginputan sidik jari, pengguna terlebih } \\
\text { dahulu mendaftarkan sidik jari dan menerima kode OTP } \\
\text { dari pesan SMS yang juga telah didaftarkan. Jika sidik } \\
\text { jari/finger print terinisialisasi maka sistem akan di } \\
\text { arahkan ke pengiriman kode OTP secara otomatis. } \\
\text { Selanjutnya kode OTP akan di input ke keypad matrix } \\
\text { untuk dapat membuka pintu. Jika penginputan kode } \\
\text { OTP berhasil, maka solenoid door lock dan sensor } \\
\text { Magnet MC-38 akan terbuka. }\end{array}$ \\
\hline 2. & $\begin{array}{l}\text { Bagaimana sistem pengujian sidik jari/finger } \\
\text { print yang salah? }\end{array}$ & $\begin{array}{l}\text { Untuk pengujian sidik jari yang salah/finger print } \\
\text { penulis menguji dengan pola sidik jari yang belum } \\
\text { terdaftar sebelumnya. Jika sidik jari/finger print tidak } \\
\text { dapat terinisialisasi, maka buzzer akan berbunyi, serta } \\
\text { solenoid door lock dan sensor Magnet MC-38 akan tetap } \\
\text { terkunci. Dari sidik jari/finger print yang tidak sesuai } \\
\text { maka sistem akan kembali pada tampilan awal. }\end{array}$ \\
\hline 3. & $\begin{array}{l}\text { Bagaimana sistem pengujian ketika kode OTP } \\
\text { salah? }\end{array}$ & $\begin{array}{l}\text { Untuk menuju pada pengujian kode OTP, penulis } \\
\text { terlebih dahulu menguji inisialisasi sidik jari. Jika sidik } \\
\text { jari sesuai makan sistem akan mengirimkan kode OTP } \\
\text { melalui pesan SMS. Kemudian kode OTP yang diterima } \\
\text { akan di input lewat keypad matrix. Jika dalam } \\
\text { penginputan kode OTP salah, maka buzzer akan } \\
\text { berbunyi dan menampilkan tulisan di LCD "Password } \\
\text { Salah" serta solenoid door lock dan sensor Magnet MC- } \\
38 \text { akan teetap terkunci }\end{array}$ \\
\hline
\end{tabular}

\section{KESIMPULAN}

Dari hasil ujicoba sistem keamanan ruangan dengan menggunakan finger print dan kode password sekali pakai yang dikirimkan ke nomor telepon pengguna dapat diambil beberapa kesimpulan antara lain:

a. Mikrokontroler dengan tipe ATmega238 banyak dipakai oleh beberapa keamanan seperti keamanan ruangan maupun keamanan rumah karena memiliki kecepatan dalam mengeksekusi program.

b. Sistem keamanan yang menggunakan komponen SIM GSM900A hanya dapat mengirimkan pesan ke nomor telepon pengguna yang telah diprogram.

c. Dengan menggunakan sensor pembaca sidik jari maka pemilik merasa aman dikarenakan pola sidik jari sesorang tidak sama.

\section{REFERENCES}

[1] M. Chamdun et al., "Sistem Keamanan Berlapis Pada Ruangan Menggunakan Rfid (Radio Frequency Identification) Dan Keypad Untuk Membuka Pintu Secara Otomatis," vol. 2, no. 3, pp. 187-194, 2014.

[2] Y. El Anwar, N. Soedjarwanto, and A. S. Repelianto, "Prototype Penggerak Pintu Pagar Otomatis Berbasis Arduino 
Uno ATMEGA 328P dengan Sensor Sidik Jari,” Electr. J. Rekayasa Dan Teknol. Elektro, vol. 9, no. 1, pp. 31-41, 2015.

[3] Siswanto, G. P. Utama, and W. Gata, "Pengamanan Ruangan Dengan Dfrduino Uno R3, Sensor Mc-38, Pir, Notifikasi Sms, Twitter," J. RESTI (Rekayasa Sist. dan Teknol. Informasi), vol. 2, no. 3, pp. 697-707, 2018.

[4] D. R. I. M. Setiadi, E. H. Rachmawanto, and C. A. Sari, "KOMBINASI ALGORITMA ONE TIME PAD DAN CHAOTIC SEQUENCE DALAM OPTIMASI ENKRIPSI GAMBAR,” vol. 8, no. 2, pp. 483-488, 2017.

[5] E. Yuliza and T. U. Kalsum, "Alat Keamanan Pintu Brankas Berbasis Sensor Sidik Jari Dan Passoword Digital Dengan Menggunakan Mikrokontroler Atmega 16,” J. Media Infotama, vol. 11, no. 1, pp. 1-10, 2015.

[6] F. Diani and Y. Widhiyasana, "Enkripsi SMS dengan Menggunakan One Time Pad (OTP) dan Kompresi LempelZiv-Welch (LZW)," J. Nas. Tek. Elektro dan Teknol. Inf., vol. 7, no. 3, pp. 3-8, 2018.

[7] A. A. Edilla and A. Panjaitan, "Miniatur Smart Home Berbasis SMS dan Arduino," J. Elem. Vol, vol. 5, no. 2, pp. 2840, 2019.

[8] M. R. Asad et al., "Sistem Pengamanan Pintu Rumah Otomatis VIA SMS Berbasis Mikrokontroller atmEGA 328P," vol. 3, no. 1, pp. 1-7, 2015.

[9] A. Siswanto, A. Efendi, and A. Yulianti, "Alat Kontrol Akses Pintu Rumah Dengan Teknologi Sidik Jari Di Lingkungan Rumah Pintar Dengan Data Yang Di Enkripsi,” J. Penelit. Pos dan Inform., vol. 8, no. 2, pp. 97-107, 2018.

[10] Z. Erianto and Mardainis, "Sistem Keamanan Pintu Ruangan Berbasis Mikrokontroler Atmega328 dan Pattern Unlock Smartphone Android," vol. 4, no. 2, pp. 41-48, 2018.

[11] M. C. Kause and I. Boimau, "RANCANG BANGUN ALAT PERAGA FISIKA BERBASIS ARDUINO (Studi Kasus Gerak Jatuh Bebas)," vol. 2, no. 1, pp. 13-19, 2019. 